\title{
Ett år som medisinsk redaktør
}

Jeg har vært ansatt som assisterende medisinsk redaktør i Tidsskriftet $i$ ett år. Dette er en slags opplæringsstilling i redaktøryrket. I løpet av dette året har jeg lært mye om hvordan en vitenskapelig redaksjon jobber og hvor mye arbeid som ligger bak hver enkelt artikkel. Det gjøres en rekke redaksjonelle vurderinger rundt aktualitet, nyhetsverdi, publiseringsetikk, sjangerkriterier og - ikke minst - om budskapet vil nå leseren.

I Tidsskriftets redaksjon er det ansatt rundt 30 medarbeidere i varierende stillingsprosenter, men det største og viktigste arbeidet bak våre 22 årlige utgaver utføres på dugnad av forfatterne og fagvurdererne. I hovedsak er innholdet vårt basert på spontant innsendte manuskripter, og alle publiserte vitenskapelige artikler er vurdert av to eller flere kolleger med spesiell kompetanse på det aktuelle området. Fagfellevurdering er tidkrevende gratisarbeid, men avgjørende for kvaliteten på det vi publiserer. Uten slik ekstern faglig vurdering kunne ikke Tidsskriftet kalle seg et vitenskapelig tidsskrift.

Mesteparten av min arbeidstid tilbringes foran en PC-skjerm, der jeg leser og redigerer manuskripter. Som redaktør kan man bli lurt av forfatteres forførende ordbruk eller en imponerende tittel, bli revet med av et treffende debattinnlegg eller et spennende forskningsfunn. For å sikre seg mot feilvurderinger blir alle manuskripter lest av flere redaktører, og ingen vitenskapelige manuskripter blir godkjent for publisering uten at de er blitt grundig diskutert på minst to redaksjonsmøter.

Tematisk har manuskriptene vi får tilsendt stor spennvidde - det dreier seg om alt fra meningsytringer til nyoppdagede mutasjoner. Felles for alle er at forfatterne ønsker å formidle et budskap til leseren. Dette lykkes de med i varierende grad. Det viktigste jeg har lært i løpet av dette året i Tidsskriftet er at når man skriver, må man ha en klar formening om hvilket budskap man vil formidle og hvem målgruppen er.

Tidsskriftets primære målgruppe er norske leger. Vår målsetting er å være et organ for utdanning, stimulere til faglig vedlikehold, forskning og fagutvikling, bidra til holdningsdanning, fremme den helsepolitiske debatten og være et medlemsblad for Den norske legeforening (1). Dette er et ambisiøst mål. Norske leger er en heterogen gruppe - de er unge og gamle, arbeider innen ulike fagfelter og har vidt forskjellige interesser. Tidsskriftet skal være et samlingspunkt for alle. Det gjør det utfordrende å være forfatter hos oss.
Tidsskriftet følger de etiske normene i Vær varsom-plakaten. Her står det blant annet at man skal «legge vekt på saklighet og omtanke $i$ innhold og presentasjon og gjøre klart hva som er faktiske opplysninger og hva som er kommentarer» (2). Uavhengig av hva et manuskript handler om, samarbeider jeg med forfatter(ne) for å presentere et budskap som er tydelig, saklig og ærlig. Spesielt viktig er det å gjøre det klart hva som representerer forfatters meninger og hva som kan begrunnes vitenskapelig. Som Charlotte Haug, tidligere sjefredaktør, sa til meg: «Her i Tidsskriftet kan man si noe om det meste, men det er måten man gjør det på som er det avgjørende.»

Mange forfattere har spesialkompetanse eller er på annen måte dypt inne i temaet de skriver om. Dette er i all hovedsak positivt, for det gir oss manuskripter med engasjement og faglig tyngde. Imidlertid kan det også føre til at budskapet blir vanskelig tilgjengelig for en leser som ikke på forhånd har satt seg inn i temaet. På medisinstudiet lærte vi at legen må møte pasienten der pasienten er. Dette gjelder også forfattere - for å bli lest og forstått må man møte leseren der leseren er - og det er gjerne et annet sted enn der forfatteren befinner seg. Som redaktør er jeg bindeleddet mellom forfatter og leser, og en av mine mest sentrale oppgaver er å hjelpe forfatteren med å formidle sitt budskap til en bred målgruppe. Som redaktør stiller jeg derfor ofte forfatterne disse spørsmålene: Hva ønsker du å fortelle? I hvilken sammenheng skal dette leses? Hvorfor skal norske leger vite dette?

Tidsskriftets redaksjon har ingen selvstendig agenda utover Tidsskriftets målbeskrivelse (1). Vi er helt avhengig av et nært samarbeid med legene for å nå målene våre, og vi ønsker hele tiden tilbakemeldinger på hva vi kan gjøre for å bli bedre. Som forfatter i Tidsskriftet får man ofte oppmerksomhet blant kolleger, og man har gode muligheter til å sette ting på dagsordenen ved at artiklene fanges opp i sosiale medier og i dagspressen. Redaksjonen ønsker å være en medspiller som sammen med forfatteren bearbeider manuskriptet slik at budskapet når frem til leserne på en tydelig og korrekt måte.

\footnotetext{
Litteratur

1. Om Tidsskriftet. http://tidsskriftet.no/Meta/Om-Tidsskriftet (28.6.2015).

2. Pressens faglige utvalg. Vær varsom-plakaten. http://presse.no/pfu/ etiske-regler/vaer-varsom-plakaten/ (28.6.2015).
} 